\title{
Populations of larvae of Anopheles spp. in natural breeding sites in Western Venezuela, an area of refractory malaria*
}

\section{População de larvas de Anopheles spp. em criadouros naturais em área de malária refratária da Venezuela Ocidental}

\author{
Eliana Rojas*t, Eric Brown**, Clistenes Rosas*t, José V. Scorza** \\ ROJAS, E. et al. Populations of larvae of Anopheles spp. in natural breeding sites in Western \\ Venezuela, an area of refractory malaria. Rev. Saúde públ., S. Paulo, 26: 336-42, 1992 . \\ Studies have been un dertaken into on the diversity and relative abundance of larvae of \\ Anopheles (Nyssorhynchus) spp. in 22 permanent or temporary pools in an area of $70 \mathrm{~km}^{2}$ in \\ the eastern piedmont of the Venezuela Andes, between the mountains and the plains, an area \\ in which malaria is refractory and $A$. nuñeztovari is present. Twelve species were identified, \\ the most frequent, abundant and sympatric being $A$. triannulatus, $A$. albitarsis, $A$. nuñeztovari, \\ $A$. oswaldoi and $A$. strodei. The samples from the permanent pools showed greater diversity \\ of species and greater numbers of larvae than the samples from the temporary pools. The \\ existence of the same larval associations in pools of other localities in the eastern piedmont \\ of the Venezuelan Andes suggests the possibility of the making an ecological map of the breed- \\ ing sites of $A$. nuñeztovari and for these anophelines in a region extending for $430 \mathrm{~km}$.
}

Keywords: Anopheles. Ecology, vectors. Fresh water.

\section{Introduction}

Anopheles nuñeztovari Gabaldon, 1940 in the main vector of malaria in the Western of Venezuela. Its exophilic behavior is considered to be the factor responsible for the refractoriness of endemic malaria to conventional control methods (Gabaldon ${ }^{12}$, 1978).

Conn ${ }^{2}$ (1990) has recently made a genetic study of the larval chromosomes of 4 populations of $A$. nuñeztovari in an area covering $760 \mathrm{~km}^{2}$, located at the junction of the states of Tachira, Apure and Barinas, and found that all belong to a single panmitic population, chromosomally identical to the cytotype identified by Kitzmiller ${ }^{16}$ et al. (1973).

The persistance of malarial transmission within $19,138 \mathrm{~km}^{2}$ of western Venezuela, populated by more than half a million people, has led to the conclusion that: Nothing can be done to eradicate malaria by the means known and available at the present time. These last 20 years have clearly indicated that under these circumstances success is impossible whatever the efforts made. (Gabaldon ${ }^{11}$,

\footnotetext{
* This work received finantial support from TDR ID880346, World Health Organization Project.

* Centro de Investigacions "José W. Torrealba" - Trujillo Reprints: J.V.Scorza - Apartado 100, - Trujillo, Venezuela
}

1983). The exophilic nature of $A$.

nuñeztovari has disproved the value of domiciliar spraying, and turned attention to control of larval populations. This demands study of the permanent breeding sites which maintain the species during the dry season, when the numerous breeding pools available to the insect during the rainy season have disappeared.

Two new methodologies have been proposed for the control of malaria vectors in similar situations: 1) detection, identification and classification of larval habitats by remote sensing scanners Hayes ${ }^{15}$ et al. 1985) and 2) integrated biological control of the larvas, with the use of use of pathogens (Stern ${ }^{20}$ et al. 1959).

In order to apply remote sensing scanners, and the subsequent biological control methods, it is necessary first to delinreate an area that is typical of the natural habitat of $A$. nuñeztovari, as well as to estimate the larval abundance in both wet and dry seasons.

We have selected for the present study the locality of Piscuri Ayari, in the state of Barinas, where the abundance of $A$. nuñeztovari, measured by the nightly man-biting rate (Gabaldon ${ }^{12}$, 1978) appeared to be satisfactory for the study of this epecies (Kitzmiller, et al. ${ }^{16,}$ 1973; Conn ${ }^{2}$, 1990). In addition, recent studies have been 
made on the natural Plasmodium infections and, biting behaviours of the adults in this area (Rubio ${ }^{19}$ et al., 1991).

Nothing is known of the center of dispersion of $A$. nuñeztovari within its extensive home range; the first objetive of the present study has been to determine whether the locality chosen is in fact characteristic for this species.

\section{Material and Method}

\section{Local Characteristics}

Location: The area proposed for the survey is a rectangle of $70 \mathrm{~km}^{2}$ of fluvial terraces, $210-500$ meters above mean sea level and in the same place as used for previous entomological studies on the adult Anopheles spp. population. The study area is traversed by the principal east-west highway from Barinas to Tachira. Four roads passable by ordinary vehicles lead to the North, toward the piedmont. These continue as horse trails toward the high terraces, passable by four-wheel traction vehicles during the dry season.

Climate: Tropical rain forest with seasonal semideciduous trees, characteristic of the lower mountain slopes with a rainfall peak between April and July, concentrating $66 \%$ of the annual precipitation. Rainfall decreases from August to December, and between January and March only $4 \%$ of the annual rain falls.

Malaria at present: The study area is at the junction of 3 municipalities, with a total of 38,320 inhabitants. In the dry season, when the density of $A$. nuñeztovari is lowest, (Gabaldon ${ }^{12}$, 1978) the incidence of malaria is highest. Between January and March of 1990, 960 cases of malaria were recorded; the same period in 1991 produced 2,241 cases of Plasmodium vivax infections. These are incidences of between $156-960$ per 10,000 of the population.

Previous observations: Surveys made in January and February of 1990 located pools, which according to information of the populace, were permanent during the dry season. After April, when $230 \mathrm{~mm}$ of rain had fallen, we found other recently formed pools. Figure 1 shows permanent pools found, as also and the area where there were only temporary pools.

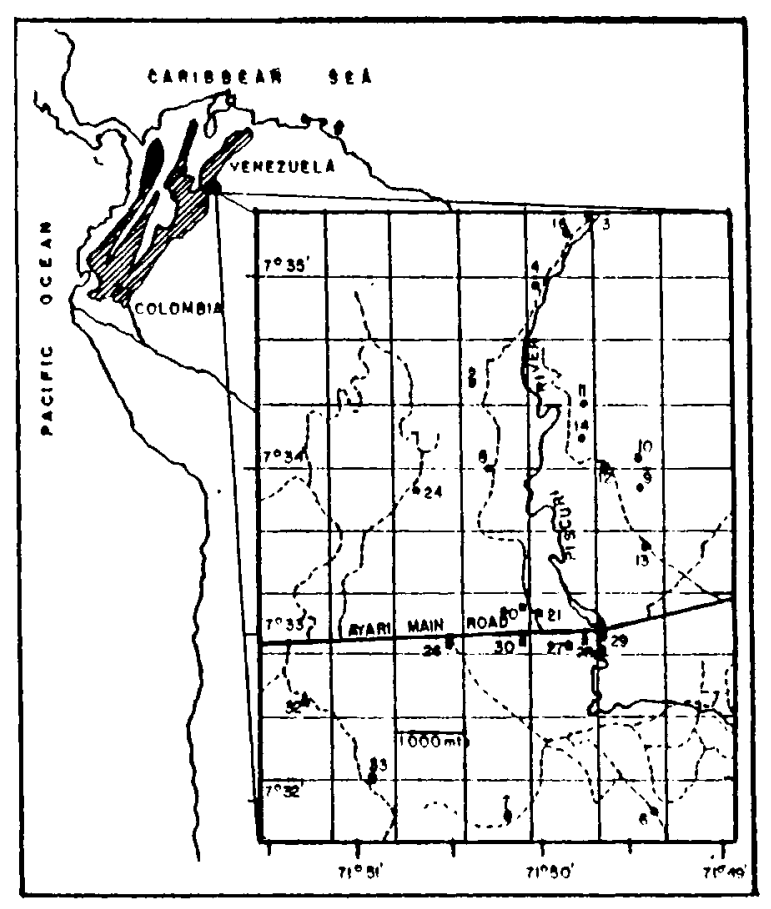

Figure 1. Area of Piscuri - Ayarí in eastern slopes of the Venezuelan Andes showing permanent (-) and temporary pools (a) breeding sites of Anopheles.

\section{Sampling Method}

Monthly samples were taken from each pool, during the period February 1990 February 1991, for the capture of the larvae of Anopheles spp. with a standard 2.5 liter dipper, 25-28 dips per site. The III and IV stage larvae were purged with $5 \% \mathrm{MgSO}_{4}$, fixed with McGregor, and mounted semipermanently with Nesbit-Berlesse. Identifications were made with the keys of Cova-Garcia \& Sutil ${ }^{4}$ (1977) and Faran \& Linthicum $^{10}$ (1981).

\section{Results}

1. Larvae of Anophheles spp. found in the pools.

Samplings fron 22 pools discovered 12 species in the permanent breeding sites and 8 of the same species in the temporary pool. During the whole year, from 5 to 20 samples were taken from each pool, $10.5 \pm$ 3.8 average from the permanent pool, and 
$7.5 \pm 3.0$ averange from the temporary pool. Tables 1 and 2 show, for each pool, the number of samples of each species, and the total number of larvae per sample.

2. Analysis of similarity between temporary and permanent pools, by the presence of recorded Anopheles species.
A cluster analysis was made for two types of pool, giving a dendrogram of simple unions, and also, the respective matrices of similarity according to the test of Sörensen. (Tabela 3 and 4; Figures 2 and 3). No great differences in species composition were observed between permanent and temporary pools. There was,

Tabela 1. Larvas of Anopheles spp. captured in permanent pools, number of larvae per pools, number of larvae per sample. Total number of larvae for all permanent pools, and percentage of each species in the grand total.

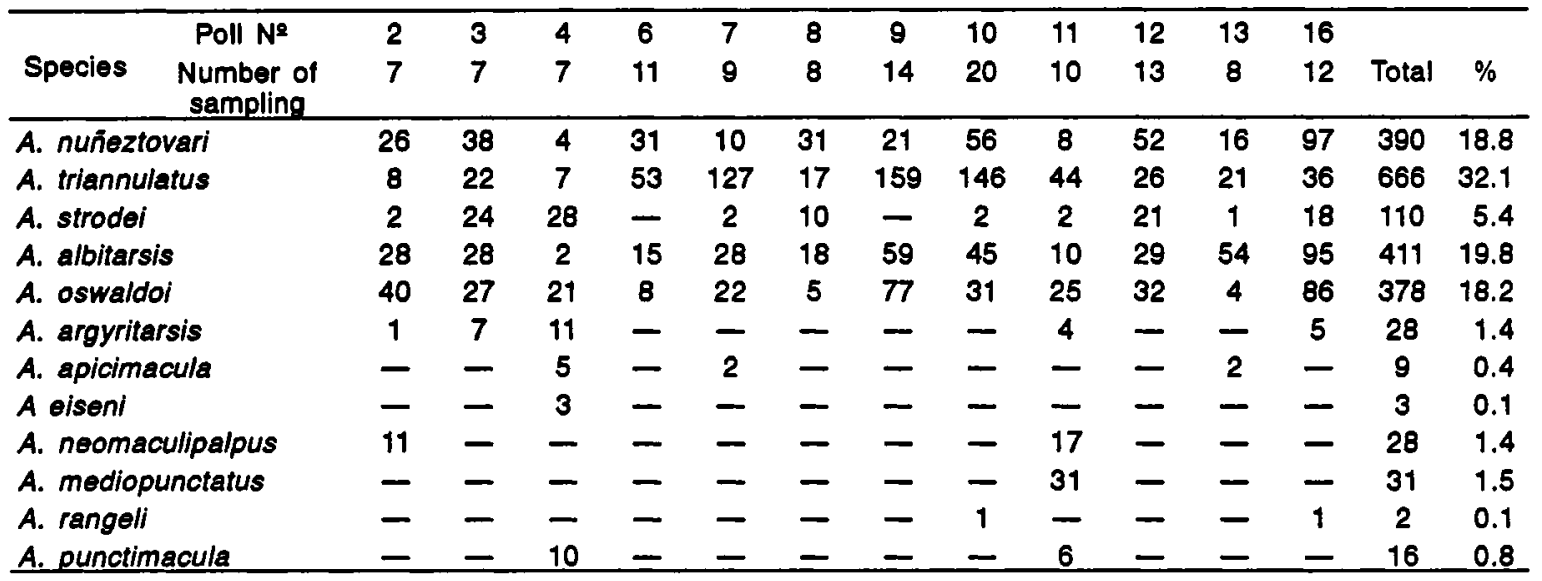

Tabela 2. Larvae of Anopheles spp. captured in temporary pools, number of larvae per pools, number of larvae per sample. Total number of larvae for all temporary pools, and percentage of each species in the grand total.

\begin{tabular}{lcccccccccccc}
\hline $\begin{array}{c}\text { Poll Necies } \\
\text { Number of } \\
\text { sampling }\end{array}$ & $\mathbf{2 2}$ & 21 & 24 & 26 & 27 & 28 & 29 & 30 & 32 & 33 & \\
& 6 & 10 & 6 & 5 & 7 & 6 & 12 & 13 & 5 & Total & $\%$ \\
\hline A. nuñeztovari & 10 & 4 & 12 & 14 & 26 & 4 & 30 & 44 & 20 & 16 & 199 & 20.5 \\
A. triannulatus & 9 & 23 & 25 & 9 & 4 & 3 & 20 & 79 & 138 & 22 & 332 & 34.3 \\
A. strodei & - & - & 1 & 1 & - & 1 & 4 & 1 & - & - & 8 & 0.8 \\
A. albitarsis & 8 & 16 & 96 & 45 & 9 & 4 & 9 & 101 & 38 & 12 & 338 & 34.9 \\
A. oswaldoi & 2 & 10 & 7 & 1 & 12 & 4 & 9 & 16 & 18 & 8 & 87 & 9.0 \\
A. argyritarsis & 1 & - & - & - & - & - & - & - & - & - & 1 & 0.1 \\
A. neomaculipalpus & - & - & - & - & - & - & - & - & - & 3 & 3 & 0.3 \\
A. rangell & - & - & - & - & - & - & - & - & - & - & 1 & 0.1 \\
\hline
\end{tabular}

Tabela 3. Matrix of similarity according to the Söurensen Test for 12 permanent breeding sites.

\begin{tabular}{|c|c|c|c|c|c|c|c|c|c|c|c|c|}
\hline & 2 & 3 & 4 & 6 & 7 & 8 & 9 & 10 & 11 & 12 & 13 & 16 \\
\hline 2 & 0.0 & 0.9 & 0.7 & 0.9 & 0.9 & 1.0 & 0.9 & 0.9 & 0.7 & 1.0 & 0.4 & 0.8 \\
\hline 3 & & 0.0 & 0.9 & 0.8 & 0.8 & 0.9 & 0.8 & 0.8 & 0.8 & 0.9 & 0.7 & 0.9 \\
\hline 4 & & & 0.0 & 0.6 & 0.8 & 0.7 & 0.6 & 0.7 & 0.8 & 0.7 & 0.7 & 0.8 \\
\hline 6 & & & & 0.0 & 0.8 & 0.9 & 1.0 & 0.8 & 0.6 & 0.9 & 0.9 & 0.7 \\
\hline 7 & & & & & 0.0 & 0.9 & 0.8 & 0.8 & 0.7 & 0.9 & 0.7 & 0.8 \\
\hline 8 & & & & & & 0.0 & 0.9 & 0.9 & 0.8 & 1.0 & 0.9 & 0.8 \\
\hline 9 & & & & & & & 0.0 & 0.8 & 0.6 & 0.9 & 0.9 & 0.7 \\
\hline 10 & & & & & & & & 0.0 & 0.7 & 0.9 & 0.9 & 0.6 \\
\hline 11 & & & & & & & & & 0.0 & 0.7 & 0.6 & 0.8 \\
\hline 12 & & & & & & & & & & 0.0 & 0.8 & 0.4 \\
\hline 13 & & & & & & & & & & & 0.0 & 0.5 \\
\hline 16 & & & & & & & & & & & & 0.0 \\
\hline
\end{tabular}

Tabela 4. Matrix of similarity according to the Söurensen Test for 10 temporary breeding sites.

\begin{tabular}{|c|c|c|c|c|c|c|c|c|c|c|}
\hline & 20 & 21 & 24 & 26 & 27 & 28 & 29 & 30 & 32 & 33 \\
\hline 20 & 0.0 & 0.7 & 0.7 & 0.8 & 0.9 & 0.8 & 0.8 & 0.8 & 0.9 & 0.8 \\
\hline 21 & & 0.0 & 0.7 & 0.7 & 0.7 & 0.7 & 0.7 & 0.7 & 0.8 & 0.7 \\
\hline 24 & & & 0.0 & 0.9 & 0.8 & 0.9 & 0.9 & 0.9 & 0.8 & 0.9 \\
\hline 26 & & & & 0.0 & 0.9 & 1.0 & 1.0 & 1.0 & 0.9 & 0.8 \\
\hline 27 & & & & & 0.0 & 0.9 & 0.9 & 0.9 & 1.0 & 0.9 \\
\hline 28 & & & & & & 0.0 & 1.0 & 1.0 & 0.9 & 0.9 \\
\hline 29 & & & & & & & 0.0 & 1.0 & 0.9 & 0.8 \\
\hline 30 & & & & & & & & 0.0 & 0.9 & 0.8 \\
\hline 32 & & & & & & & & & 0.0 & 0.9 \\
\hline 33 & & & & & & & & & & 0.0 \\
\hline
\end{tabular}




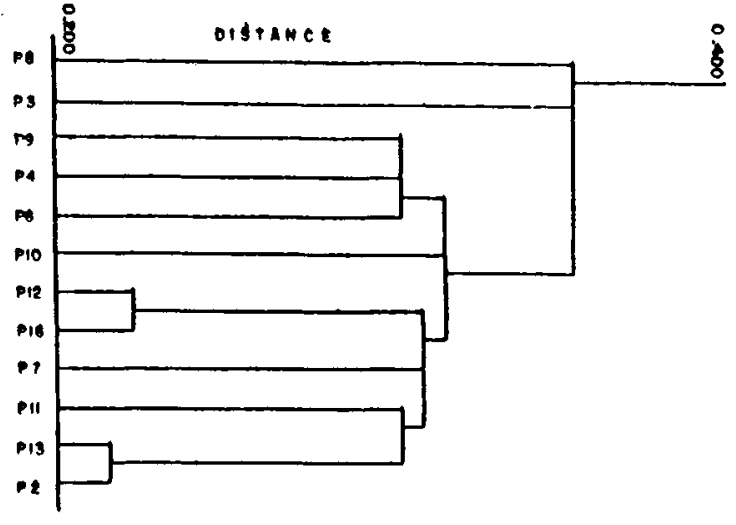

Figura 2. Dendrogram of simple unions from cluster analysis between 12 permanent pools breeding sites for 5 dominants Anopheles species.

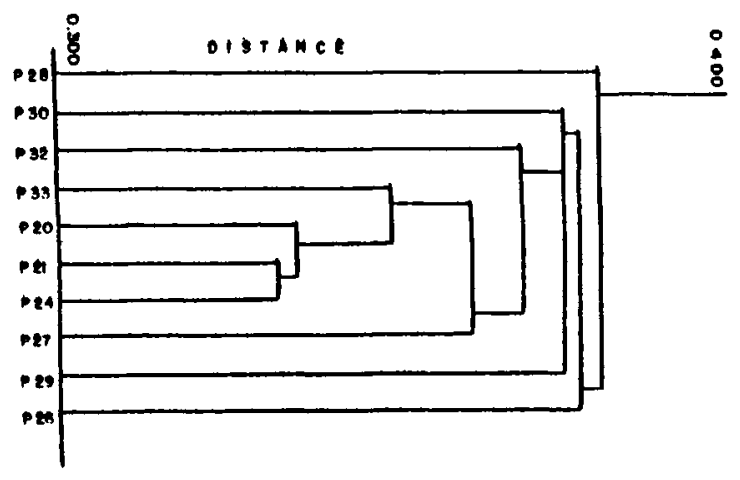

Figura 3. Dendrogram of simple unions from cluster analysis between 10 temporary pool breeding sites for 5 dominants Anopheles species.

Tabela 5. Indices of affinity and of " $t$ " between the 5 Anopheles spp. most frequent and abundant in natural breeding sites of Ayari . Piscuri in Western Venezuela $(t=1.645)$

\begin{tabular}{|c|c|c|c|c|c|}
\hline \multicolumn{2}{|c|}{ Constrasted specie } & \multicolumn{2}{|c|}{$\begin{array}{l}\text { Permanent } \\
\text { Pools }\end{array}$} & \multicolumn{2}{|c|}{$\begin{array}{c}\text { Temporary } \\
\text { Pools }\end{array}$} \\
\hline & & $\mathrm{I}_{\mathrm{AB}}$ & $t$ & $I_{A B}$ & $t$ \\
\hline A. nuñeztovari & - A.triannulatus & 1 & 4.39 & 1 & 3.92 \\
\hline$" \quad n$ & - A. albitarsis & 1 & 4.39 & 1 & 3.92 \\
\hline$n$ & - A. oswaldoi & 1 & 4.39 & 1 & 3.92 \\
\hline$n$ & - A. strodei & 0.85 & 2.91 & 0.75 & 2.57 \\
\hline A.triannulatus & - A. albitarsis & 1 & 4.39 & 1 & 3.92 \\
\hline 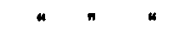 & - A. oswaldoi & 1 & 4.39 & 1 & 3.92 \\
\hline$n$ & - A. strodei & 0.85 & 2.91 & 0.75 & 2.57 \\
\hline A. albitarsis & - A. oswaldoi & 1 & 4.39 & 0.75 & 2.57 \\
\hline$n$ & - A. strodei & 0.85 & 2.91 & 0.75 & 2.57 \\
\hline A. oswaldoi & - A. strodei & 0.85 & 2.91 & 0.75 & 2.57 \\
\hline & & $\mathrm{N}: 12$ & $x=0.05$ & $N: 10$ & $x=0.05$ \\
\hline
\end{tabular}

however, greater variability in the temporary pools where the range of calculated distance was of from 3.00 to 4.00 .

\section{Interspecific affinity.}

The test of Fager ${ }^{7}$ (1957) indicates a real interspecific affinity when $t$ is greater than 1,645 . Table 5 shows the indices of affinity between the 5 dominant Anopheles species found in the pools. $A$. nuñeztovari has a high and constant association with $A$. triannulatus, $A$. albitarsis and $A$. oswaldoi. $A$. triannulatus also associates with $A$. albitarsis and $A$. oswaldoi.

4. Observations upon the dominant Anopheles species in the breeding sites.

In the 22 pools examined, 3,041 III and IV stage larvas were taken: 2,072 in the 12 permanent pools and 969 in the 10 temporary pools. The average number of samples per pool was $10.5 \pm 3.8$ over the 12 months for the permanent pools, and 7.5 \pm 3.0 over the 8 months of the rainy season for the temporary pool. In the permanent pools the number of larvae taken varied from 81 to 338 , while in the temporary pools, it varied from 30 to 241 . These differences are not attributable to the number of samples taken but to the other factors influencing the stability of the permanent pools.

In certain of the pools, there predominated species of the subgenus (Nyssorhynchus): A.nuñeztovari, A. triannulatus, $A$. strodei, $A$. albitarsis and $A$. oswaldoi. In the permanent pool, these species formed $94.3 \%$ of the population, and in the temporary pools, $99.5 \%$, with the exception of $A$. strode $i$, which appeared in 10 of the permanent pools and in 5 of the 10 temporary pools. These dominant species shared the habitat completely, considering that dipping samples were taken in all cases from areas no greater than $4 \mathrm{~m}^{2}$.

The relative abundance of the larvae of each species is shown in Figures 4 and 5 , expressed as ratios of the numbers of III and IV stage larvae of each species per sampling and per pool.

Apart from the greater abundance of $A$. triannulatus and the lower number of $A$. strodei in some of the permanent or temporary pool, there may be a certain 
competition toward exclusion between $A$. triannulatus and $A$. nuñeztovari, most evident in the permanent pools. This, however, my be merely a chance phenomenon. It occurs in 5 of the 12 permanent pools.

\section{Discussion}

In western Venezuela, the area of malaria refractory to control by domiciliary spraying with DDT occupies $19,000 \mathrm{~km}^{2}$, 270 times the area of our study. Its principal vector is $A$. nuñeztovari, although $A$. albitarsis may play a lesser role (Gabaldon ${ }^{11}, 1983$ ). In Colombia, in the region between 4 and 9 degrees $N$, on the eastern and western slopes of the eastern Andes, A. nuñeztovari, a highly exophilic vector, is responsible for malaria, in part transmitted mainly inside sprayed houses by vectors that, although susceptible to insecticide in use, are not reduced sufficiently in numbers" (Elliott ${ }^{6}, 1968$ ). The distribution of $A$. nuñeztovari in Colombia in the west extends to Bajo Calima, in Buenaventura, where it forms $54 \%$ of anophelines that bite man (Fajardo \& Alzate $\left.{ }^{8}, 1987\right)$.

The results reported here might be extrapolated for the whole area of distribution of $A$. nuñeztovari in the piedmont of the Venezuelan Andes, with the aim of elaborating an ecological map as a basis for a program of integrated larval control. The following points have been established by this project: 1) larvae of $A$. nuñeztovari were present in all 22 pools sampled, permanent or temporary; 2) the association of $A$. nuñeztovari with 5 other species of the subgenus Nyssorhynchus, these species forming more than $94 \%$ of all III and IV stage larvas captured during the year is clear; 3) A. nuñeztovari was found at every breeding site, composing up to $20 \%$ of the larval population, a density similar to that of $A$. albitarsis.

Extrapolation of these findings depends, firstly, on the correct identification of these species, in view of the extensive geographic distribution and the known genetic polymorphism of anophelines in general.

Conn ${ }^{2}(1990)$ has made a genetic study of $A$. nuñeztovari in western Venezuela and found it to be identical to the form in northern Colombia. Kitzmiller et al. ${ }^{16}$ (1973) have reported differences between 2 populations of the Brazilian Amazon.

Although $A$. triannulatus has been recognized by Faran ${ }^{9}(1980)$ as a monotypic species well defined morphologically, Galvão \& Lane ${ }^{14}$ (1941) recognized 2 subspecies: $A$. t. triannulatus and A. t. davisi, and Conn ${ }^{1}$ (1991), on analysing cytogenetically 2 populations of $A$. triannulatus from western Venezuela - one from Guaquitas in our study area - has confirmed the unique character of their autosomic associations, thus supporting the morphological placement of this species within the subgroup Triannulatus of the section Albimanus.

A. albitarsis has been identified by following the keys of Stojanovich ${ }^{21}$ et al. (1966) and of Cova-Garcia \& Sutil ${ }^{4}$ (1977), and we have also compared the description of Linthicum ${ }^{17}$ (1988), who examined material from Argentina, Brazil and Paraguay. Recently, Rosa-Freitas \& Deane ${ }^{18}$ (1989) have described a neotype of $A$. albitarsis from material collected at the type locality - Baradero, Argentina - which may be useful for further infraspecific taxonomic studies. Although Linthicum ${ }^{17}$ (1988) considers that $A$. albitarsis is present only in Argentina, Paraguay and southern Brazil, the identification of the material from western Venezuela has been maintained as $A$. albitarsis and not $A$. marajoara, although we have not compared our specimens with the recently published neotype.

Aside from taxonomy, the zoogeography of $A$. nuñeztovari and the species sympatric to it should be discussed. The zoogeography of Venezuelan anophelines has been systematized by Gabaldon \& Cova-Garcia ${ }^{13}$ (1952), who assingned some 60 species to the region, considering the country to belong to the Brazilian subregion. Of the 12 species of Anopheles found in our study area, with the exception of $A$. argyritarsis widely distributed in the whole Neotropical region, $A$. nuñeztovari, $A$. rangeli, and $A$. medipunctatus occur exclusively in the Brazilian subregion.

In the anopheline breeding sites in our area, then, there are associations of the larvae of 3 strictly Brazilian species, together with larvae of 9 other more widely. 
distributed species. In these associations, $A$. triannulatus is the dominant species, occuring in conjunction with $A$. albitarsis, $A$. nuñeztovari, and $A$. oswaldoi. A fifth species, $A$. strode $i$, is present in smaller numbers. Similar associations have been found by Deane ${ }^{5}$ et al. (1948) in the Northwest and in the Amazon Region of Brazil. In the State of Pará, adults $A$. nuñeztovari, $A$. albitarsis, and $A$.

triannulatus, were found together with $A$. darling $i$ and $A$. aquasalis, the last 2 species being absent from our collections, although they are abundant in southern Venezuela and on the northern coast. Fajardo \& Alzate $^{8}$ (1987) reported the presence of larvae of $A$. nuñeztovari associated with $A$. rangeli, $A$. strode $i$ and $A$. oswaldoi in the Bajo Calima of Buenaventura, Colombia, but did not report A. triannulatus, although Faran \& Linthicum ${ }^{10}$ (1981) report the range of this species as covering the whole territory of Colombia.

Anopheline larval associations in Venezuela have been intensively studied by Cova-Garcia ${ }^{3}$ (1951). Unfortunately, $A$. nuñeztovari was not included in that study, the data the author analyzed deriving from collections made between 1938 and 1945 . On the assumption that the 11 anopheline species, excluding $A$. nuñeztovari, dealt with by Cova-Garcia ${ }^{3}$ (1951), prefer the same aquatic habitats, paid particular attention has been point in this present study to the information from the readings at breeding sites in and near the cities of Acarigua and Guanare in the extreme nottheast piedmont of the Venezuelan Andes. In pools of this region, $A$. triannulatus was the most abundant species, associated with $A$. albitarsis, $A$. oswaldo $i$ and $A$. strodei. Cova-garcia ${ }^{3}$ (1951) reported that, in Acarigua and Guanare, A.triannulatus was associated wiht $\mathrm{A}$. albitarsis (78.1 and $14.9 \%$ ), with $A$. oswaldoi (11.3 and $7.9 \%$ ), with $A$. punctimacula (12.6 and $3.2 \%$ ) and with $A$. neomaculipalpus (8.0 and $4.6 \%$ ) respectively, while only in Acarigua was it associated with $A$. stroide $i$ and A.apimacula, (29.4 and 9.1\%).

It may be presumed, and may eventually be confirmed that, in Acarigua and Guanare, $A$. nuñeztovari will be found to occur, in proportions similar to those reported for the association between $A$. triannulatus and $A$. albitarsi.

\section{Conclusions}

1. Anopheles nuñeztovari, the principal malaria vector in western Venezuela, has been studied in breending sites of 22 natural accumalations of water, temporary or permanent, within an area of $70 \mathrm{~km}^{2}$, located in the southeast piedmont of Venezuelan Andes, between the mountains and the plains.

2. The larvae of A.nuñeztovari were associated with 4 other species of the subgenus Nyssorhynchus, principally with $A$. albitarsis, considered to be a secondary malaria vector.

3. There is great similarity between the temporary and permanent pools, considered separately, although in the permanent pools there were more larvae and great variety species per sample.

4. There appears to be a certain exclusion between A.trinnulatus and A.nuñeztovari in the permanent pools, and a like exclusion between $A$. trinnulatus and $A$. albitarsis in the temporary pools.

5. Athough the anopheline species reported here are typical of the Brazilian subregion, they are not always found associated in other countries, especially when other species such as $A$. darling $i$ and $A$. aquasalis are present, these latter being dominant in places.

6. The association of $A$. trinnulatus (lacking information on $A$. nuñeztovari) with $A$. albitarsis $A$. oswaldo $i$ and $A$. strode $i$, in pools of other sites in western Venezuela, and always in the eastern piedmont of the Andes, tends to support the hypothesis that such a relationship of sympatry is commun in the breeding sistes of Anopheles spp. in the eastern piedmont of the Venezuelan Andes, where malaria is refractory.

\section{Acknowlegment}

To Dr. Robert Zimmerman from Pan American Health Organization, Maracay, Venezuela, during the planning and carrying out of this work.

ROJAS, E. et al. População de larvas de Anopheles spp em criadouros naturais em área da malária refratária da Venezuela Ocidental. Rev. Saúde públ., S.Paulo, 26: 336-42, 1992. Tem-se estudado a diversidade e a riqueza de larvas de Anopheles (Nyssorhynchus) spp. em 22 postos permanentes e temporais 
em área de $70 \mathrm{~km}^{2}$ ao pé da Cordilheira Andina Oriental da Venezuela, em região de malária refratária. Foram identificadas 12 espécies, sendo as mais freqũentes, abundantes e simpátricas as $A$. triannulatus, $A$. albitarsis, $A$. nuñeztovari, $A$. oswaldoi $y$ $A$. strodei. Foi maior o número de espécies e de larvas por amostra nos postos permanentes do que nos temporais. A existência das mesmas associações larvais, em postos de outras localidades, ao pé da Cordilheira Andina Oriental da Venezuela, baseia-se no ponto de vista de que é possível fazer-se um mapa ecológico dos criadouros dessas espécies de Anopheles em região de $430 \mathrm{~km}$ de extensão.

Descritores: Anopheles. Ecologia de vetores. Água doce.

\section{Referências Bibliográficas}

1. CONN, J. A cytogenetic analysis of the polytene chromosomes of Anopheles triannulatus (Diptera: Culicidae) from western Venezuela. Genome, 34: 267-72, 1991.

2. CONN, J. A genetic study of the malaria vector Anopheles nuñeztovari from westem Venezuela. $J$. Amer. Mosq. Contr. Assoc., 6: 400-5, 1990.

3. COVA-GARCIA, P. Distribuición geográfica y datos taxonómicos de los anofelinos de Venezuela. Caracas, Imprenta Nacional, 1951.

4. COVA-GARCIA, P. \& SUTIL, E. Clave para larvas de anofelinos de Venezuela. Bol. venez Dir.Malar. Saneam. Amb.., 15: 6-26, 1977.

5. DEANE, L.M. et al. Notas sobre a distribuicão e a biologia dos anofelinos das regiōes nordestina e amazônica do Brasil. Rev. Fund SESP, 1: 827-965, 1948.

6. ELLIOTT, R. Studies on man-vector contact in some malarious areas in Colombia. Bull. wld Hlth Org., 38: 239-53, 1968.

7. FAGER, E. Determination and analysis of recurrent groups. Ecology, 38: 586-95, 1957.

8. FARJADO, P. \& ALZATE, A. Anopheles nuñeztovari como vector de malaria en el Bajo Camila, Buenaventura. Colombia med, 186: 14-8 1987.

9. FARAN, M.E Mosquito studies (Diptera: Culicidae) XXXIV. A revision of the Albimanus section of the subgenus Nyssorhynchus of Anopheles. Amer. Entomol. Inst., 15: 1-215, 1980.
10. FARAN, M.F. \& LINTHICUM, R.J. A handbook of the Amazonian species of Anopheles (Nyssorhynchus) (Diptera: Culicidae). Mosquito System., 13: 1-81, 1981.

11. GABALDON, A. Malaria erradication in Venezuela: doctrine, practice, and achievements after twenty years. Amer. J. trop. Med. Hyg., 32: 203-11, 1983.

12. GABALDON, A. What can and cannot be achived with conventional anti-malaria measures. Amer. J. trop. Med. Hyg., 27: 653-8, 1978.

13. GABALDON. A. \& COVA-GARCIA, P. Zoogeografía de los anofelinos de Venezuela. IV Suposición en la región Neotrópica $\mathrm{Y}$ observaciones sobre las especies de esta región. Rev. Sanid. Asist. soc., 17: 171-209, 1952.

14. GALVÃO, A.L. \& LANE, J. Observações sobre alguns anofelinos de Salobra, Mato Grosso (Diptera: Culicidade). Rev. Biol. Hyg., 11: 10-8, 1941.

15. HAYES, R.O. et al. Detection, identification, and classification of mosquito larval habitats using remote sensing scanners in earch-orbiting satellites. Bull. wld. Hith Org., 63: 361-74, 1985.

16. KITZMILLER, J.B. et al. Chromosomal differences in populations of Anopheles nuñeztovari. Bull. whd Hlih Org., 48: 435-55, 1973.

17. LINTHICUM, K.L. A revision of the Argyritarsis section of the subgenus Nyssorhynchus of anopheles (Diptera: Culicidae). Mosquito System., 20: 99-270, 1988.

18. ROSA-FREITAS, M.G. \& DEANE, L.M. The neotype of Anopheles albitarsis (Diptera: Culicidae). Mem. Inst. Oswaldo Cruz 84: 289-302, 1989.

19. RUBIO, Y. et al. Malaria vectors in westem Venezuela. Trans. roy Soc. trop. Med. Hyg., 85: $316,1991$.

20. STERN, N.M. et al. The integrated control concept. Hilgardia, 29: 81-101, 1959.

21. STOJANOVICH, C.J. et al. Clave ilustrada para los mosquitos anofelinos de Venezuela. Washington, D.C. U.S. Dep. Hith Ed. \& Weffare, Public Health. Servic., 1966. 